\title{
GENDER DIFFERENCES FAVOURING FEMALES IN LEARNING STRATEGIES IN MATHEMATICS
}

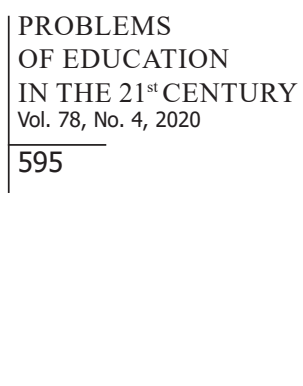

\author{
Indrek Kaldo \\ Estonian Business School, Estonia \\ Kandela Õun \\ University of Tartu Pärnu College, Estonia
}

\begin{abstract}
Most universities teach mathematics in the first year and the complexity of the subject demands also different levels of mathematics. Although students understand the reason why they need to learn mathematics, there are more than half of students struggling during the math classes. It is also interesting to compare male and female students 'study habits and differences. The aim of this research is to report first-year Estonian university students'views on mathematics by gender. The quantitative data were collected from 440 university students of different disciplines. The participants completed the LIST questionnaire what measures several aspects of learning strategies of mathematics conducted by factor analysis of 69 questions in 4-point Likert scale. In this research, in two of nine factors, females hold a more positive view of learning strategies than did male students. This research indicates which learning strategies in mathematics are preferred by males and females. Factors Organizing and Repeating were the factors in which we found statistically significant gender difference. Females showed more powerful organizing skills and had better repeating strategies than males. Females try to order the subject matter in a way that makes it easy for them to remember, they go over their notes and structure the most important points more than males. In all the other factors, statistical differences were found only in some questions. Keywords: learning strategies, LIST-questionnaire, mathematics education, mathematics related effect, university mathematics.
\end{abstract}

\section{Introduction}

At the beginning of the 1970 s, there used to be clear gender differences favouring males in large scale mathematics performance tests (Hyde et al., 1990). As numerous studies on achievement differences indicate, there is no reason to believe that female students are underrepresented in mathematics-related studies due to inferior mathematics skills (Kaldo \& Hannul 2014). Rather, female students tend to opt out of mathematics more often than male students at equal performance levels (Kaldo \& Hannula 2014). Some studies have shown that students tend to perceive mathematics as a male domain (Frost et al., 1990), but this belief is held mainly by male students and therefore does not appropriately explain why female students who perceive mathematics as gender neutral nevertheless opt out of mathematics (Kaldo \& Hannula 2014).

In Estonia at the university level more than two-thirds of the students think that what they are learning in mathematics is interesting (Kaldo, 2015). The problem in Estonia is that more than half of the students do not understand everything that they have done in mathematics over the last year (Kaldo, 2014). This calls for a change in teaching techniques in mathematics at the university level. Based on Alsina (2001) and Bergsten (2007), Kaldo (2015) suggested that the students would benefit from additional materials (tutorials, books, lecture notes, web 
Indrek KALDO, Kandela ÕUN. Gender differences favouring females in learning strategies in mathematics

PROBLEMS

OF EDUCATION

IN THE $21^{\text {st }}$ CENTURY Vol. 78 , No. 4, 2020

596

pages, etc.) for studying mathematics at home and practicing using mathematics after lectures. Moreover, because $65 \%$ of students said that mathematics is hard for them, there is a need for individual consultation times in mathematics (Kaldo, 2015).

Kaldo and Hannula (2014) found in their study a surprising result that in Estonia female students had a more positive view on mathematics than male students. Female students thought that mathematics was interesting, and they were good at mathematics (Kaldo \& Hannula, 2014). Mathematics was harder for male students than female students (Kaldo \& Hannula, 2014). Therefore, the question is raised: Is there gender difference in learning strategies of Estonian students in mathematics at the university level?

Recent data indicated that the gender difference in mathematics achievement has been eliminated (Hyde et al., 2008). Their study shows that, for grades 2 to 11, the general population no longer shows a gender difference in math skills, a result consistent with the gender similarities hypothesis, which maintains that males and females are similar in most, but not all areas. Else-Quest, et al. (2010) conducted a meta-analysis including two major international data sets, the 2003 TIMMS and PISA, representing 493495 students 14 to 16 years of age, to estimate the magnitude of gender differences in mathematics achievement, attitudes and effect across 69 nations throughout the world. Consistent with the gender similarities hypothesis, they found gender similarities in achievement, although boys reported more positive attitude and effects towards mathematics. The PISA 2018 results suggest that Estonia's education system is effective and globally, Estonian students are ranked 8th in math (OECD, 2019). In PISA 2018 in all countries and economies, girls significantly outperformed boys in reading and in Estonia, the gender gap in reading was not significantly different from the average gap. Also, in PISA in Estonia, boys outperformed girls in mathematics, but girls slightly outperformed boys in science.

In the Forgaszet al. (2004) study, an Australian sample of students indicated that they believed mathematics was more likely to be the favourite subject of girls than of boys, and that girls were more likely than boys to enjoy mathematics and to think mathematics is interesting. Unfortunately, studies of gender differences in mathematics-related beliefs at the university level are an almost unknown theme. Issues of the ICMI studies "Towards gender equity in mathematics education" and "The teaching and learning of mathematics at the university level" failed to explore this topic. Also, the special issue titled "Beliefs and Beyond: Affecting the Teaching and Learning of Mathematics" in the journal ZDM (The International Journal on Mathematics Education) in 2011 failed to touch the mathematics-related students' beliefs at the tertiary level.

Li (2007) collected data from 450 secondary students (grades 7-12) and found that in general female students in Canada hold significantly more positive attitudes toward mathematics. That is, female students tend to enjoy learning mathematics and think it is more important to learn mathematics than male students do. Steinthorsdóttir and Sriraman (2007) showed that in Iceland, significant gender differences in mathematics achievement favoured girls.

Lindberget al. (2010) meta-analysed 242 studies of gender differences in mathematics performance representing the testing data of 1,286,350 people and these studies were published between 1990 and 2007. The key finding in their study was that gender difference weighted over all studies was very small $(d=.05)$.

The results of Else-Quest et al. (2010) identify the specific domains of gender equity responsible for gender gaps in mathematics. They pointed out that gender equity in school enrolment, women's share of research jobs, and women's parliamentary representations were the most powerful predictors of cross-national variability in gender gaps in mathematics.

Studies on gender typically conclude mathematics either to be a male domain or that no gender differences are found. However, some studies show that females have a more positive attitude to mathematics than males. 
Research into mathematics education at the tertiary level may be itself an interesting field of research and may give rise to useful results for teachers in all educational levels to apply to their teaching (Alsina, 2001; Abdulwahed et al., 2012). Based on studies carried out by researchers in other countries, it is clear that learning strategies in mathematics are important areas in mathematics education and need attention, also in an Estonian context. Einaste (2013) and Rööp (2013) also conducted research about learning strategies in mathematics education, but our study also includes students from different subjects not only the students of mathematics and informatics.

Estonian university students thought that mathematics is an important, useful and valuable subject, and they have a positive view of mathematics (Kaldo, 2015). Female students held a more positive view of mathematics than males did. On the other hand, the students thought that mathematics was not attractive. Kislenko (2009) came to the same conclusion in her study of Estonian pupils. A good lecturer must know how to motivate students, must know how to use best learning strategies in mathematics and how to make mathematics more attractive for students. Therefore, the research question was raised: Do the learning strategies in mathematics at university level differ for males and females?

\section{Research Methodology}

\section{General Background}

The LIST questionnaire (Wild \& Schiefele, 1994) was first compiled in the 1990s in Germany and has since been modified several times. The 69-item LIST questionnaire focuses on cognitive, metacognitive and resource-related strategies in mathematics and in this instrument comprises 13 factors of learning strategies grouped accordingly (Griese et al., 2015).

The data were gathered in 2017 and 2018 from students of five universities of Estonia. Participants filled in a questionnaire on paper. The students were asked to respond on a 4-point Likert scale questions. The students were given at least 30 minutes to fill in the questionnaire and told the questionnaire was anonymous.

To describe students`study habits and learning strategies, an exploratory factor analysis was conducted by Kaldo and Oun (2019) and it concludes that the LIST questionnaire is also suitable for Estonian respondents. Even if there was by Kaldo and Õun (2019) 9 factors that showed at least .7 value of Cronbach alpha other 3 factors were also included into the gender difference analysis. For determining the statistically significant differences of the factors of the main values of male and female students, the t-test of independent samples was conducted. If there was statistically significant difference $(p<.05)$ items included into the factors were also tested.

Since the purpose of the research was to compare male and female 12 factors compared by gender, the same factor structure as Kaldo and Õun (2019) was used.

\section{Sample}

There are five universities in Estonia and there are respondents from all of those and also from different fields: there are students studying economy, business, marketing, aviation, geology, finance and accounting, telecommunication, electronics, informatics etc.

The respondents were 440 bachelor students taking at least one first-year compulsory math course at the university level. The questionnaire was completed during the mathematics lectures, and participation was voluntary. There were 234 males and 206 females as total 440 students (Table 1).

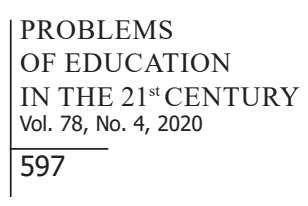


Indrek KALDO, Kandela ÕUN. Gender differences favouring females in learning strategies in mathematics

PROBLEMS

OF EDUCATION

IN THE $21^{\text {st }}$ CENTURY Vol. 78, No. 4, 2020

598

Table 1

Male and female participants $(N, \%)$

\begin{tabular}{lcccccc}
\hline & \multicolumn{2}{c}{ Females } & \multicolumn{2}{c}{ Males } & \multicolumn{2}{c}{ Total } \\
\hline & $n$ & $\%$ & $n$ & $\%$ & $n$ & $\%$ \\
\hline University of Tartu & 22 & 10.7 & 12 & 5.1 & 34 & 7.7 \\
\hline University of Tallinn & 16 & 7.8 & 33 & 14.1 & 49 & 11.1 \\
\hline Tallinn University of Technology & 81 & 39.3 & 69 & 29.5 & 150 & 34.1 \\
\hline Estonian Business School & 51 & 24.8 & 86 & 36.8 & 137 & 31.1 \\
\hline Estonian University of Life Sciences & 29 & 14.1 & 18 & 7.7 & 47 & 10.7 \\
\hline Estonian Aviation Academy & 7 & 3.4 & 16 & 6.8 & 23 & 5.2 \\
\hline
\end{tabular}

Some universities are less numbered because the lecturers of subjects did not find the proper time during the data gathering period to let students fill the questionnaires. Sample size is approximately $30 \%$ of students who have mathematics course in their study program so the database is presenting population quite well.

\section{Instrument and Procedures}

First, it needed here to clarify that the instrument used was developed not only to compare gender differences, but also to explore the factor structure for learning strategies of Estonian students in mathematics at the university level (Kaldo \& Õun, 2019). As there are no analogous Estonian questionnaires on learning strategies in mathematics, this instrument is based on the work of Griese et. al (2015) 69-LIST questionnaire which is modified and upto-date and once tested for research in Estonia (Kaldo \& Õun, 2019). In this instrument, the factor analysis confirmed nine factors in Estonia: Organizing, Elaborating, Repeating, Effort, Attention, Time management, Learning Environment, Peer Learning and Using Reference (for details, see Kaldo \& Õun, 2019).

The participants were informed that the aim of the research was to study their learning strategies in mathematics. The students were given the questionnaire on paper and they were asked to respond anonymously. This study used a 4-point scale because that scale forces the students to make a decision and not to be able to choose a neutral position. Midgley et al. (1989) also used a 4-point Likert scale in their longitudinal study of 1301 students and teachers' relations and attitudes towards mathematics. The students were given approximately 40 minutes to fill in the questionnaire.

\section{Data Analysis}

Gender differences were analysed in the different dimensions using $t$-tests for the equality of means (independent samples). The statistical program SPSS Statistics 26.0 was used for the data analysis. Norman (2010) dissected the Likert-scale analysis and showed that many studies dating back as far as the 1930s consistently showed that parametric statistics were robust with respect to violations of these assumptions. Norman (2010) also summarized that parametric statistics can be used if the answers to the questions are in Likert scale, with small sample sizes, unequal variances, or abnormal distributions, without fear of "coming to the wrong conclusion". De Winter and Dodou (2012) came to the same conclusion: Likert 
items, the $t$-test and the Mann-Whitney $U$ test generally have similar power, so researchers need not worry about finding a difference when there is none in the population. Supporting the choice of using parametric methods, authors refer here to a study of gender differences in mathematics (Else-Qyest et al., 2010) in which the PISA and TIMMS data sets were analysed using parametric methods. In addition, Field (2009) also used parametric methods for an instrument where statements were followed by a Likert scale ranging from "strongly disagree" to "strongly agree". Therefore, in this study the parametric method and $t$-test are used, which assesses whether the means of two groups are statistically different from each other. In this article t-test was used to study factors (conducted by Factor Analysis) by gender so factors are not in Likert scale anymore, but statements are.

Frequency tables are supposedly the most informative presentation of ordinal data (Kislenko, 2011). Based on the research questions, 65 statements from the survey were considered in the analysis (Kaldo \& Õun, 2015). The following analysis presents the frequency tables for every separate factor in order to give a general picture of the results and introduces the differences between genders. The percentage of the answers of every item is presented in the tables. Here, the data analysis method is mostly descriptive analysis - cross tables and frequencies. The correlation coefficients presented in this analysis are Spearman's because the data are in ordinal scale (Field, 2009; Kislenko, 2011). The presented correlations are significant at the .01 level. In addition, a chi-square test is used for comparing male and female students' answers. If there is a need to analyse whether there is a relationship between two ordinal variables, the Pearson's chi-square test is conducted (Field, 2009). For the chi-square test to be meaningful, it is imperative that each person, item or entity contributes to only one cell of the contingency table and the expected frequencies should be greater than 5 (Field, 2009).

\section{Results of Research}

There are 12 factors in 69-item LIST questionnaire one can use for Estonian dataset (Kaldo \& Õun, 2019): Organizing, Elaborating, Repeating, Effort, Attention, Time management, Learning Environment, Peer Learning and Using Reference confirmed good reliability (Chronbach alpha $>.70$ ) and three factors of Metacognition (Planning, Monitoring and Regulating) confirmed low reliability (Chronbach alpha 0.6-0.7) so those are left out from analysis. At first descriptive statistics of 9 factors were calculated for male and female students (Table 2).

\author{
PROBLEMS \\ OF EDUCATION \\ IN THE $21^{\text {st }}$ CENTURY \\ Vol. 78, No. 4, 2020 \\ 599
}


Indrek KALDO, Kandela ÕUN. Gender differences favouring females in learning strategies in mathematics

PROBLEMS

OF EDUCATION IN THE $21^{\text {st }}$ CENTURY Vol. 78 , No. 4,2020

Table 2

Factors: Mean values, standard deviation and standard error mean by gender

\begin{tabular}{|c|c|c|c|c|c|}
\hline Factors & Gender & $n$ & $\overline{\mathbf{x}}$ & $S D$ & $S E$ \\
\hline \multirow{2}{*}{ Organizing } & Female & 206 & 2.88 & .51 & .035 \\
\hline & Male & 234 & 2.50 & .54 & .035 \\
\hline \multirow{2}{*}{ Elaborating } & Female & 206 & 2.68 & .54 & .038 \\
\hline & Male & 234 & 2.77 & .53 & .034 \\
\hline \multirow{2}{*}{ Repeating } & Female & 206 & 2.51 & .54 & .038 \\
\hline & Male & 234 & 2.34 & .53 & .034 \\
\hline \multirow{2}{*}{ Attention } & Female & 206 & 2.59 & .68 & .047 \\
\hline & Male & 234 & 2.57 & .72 & .047 \\
\hline \multirow{2}{*}{ Effort } & Female & 206 & 2.87 & .51 & .035 \\
\hline & Male & 234 & 2.81 & .48 & .031 \\
\hline \multirow{2}{*}{ Time Management } & Female & 206 & 2.36 & .59 & .041 \\
\hline & Male & 234 & 2.35 & .55 & .036 \\
\hline \multirow{2}{*}{ Learning Environment } & Female & 206 & 2.86 & .54 & .038 \\
\hline & Male & 234 & 2.80 & .54 & .035 \\
\hline \multirow{2}{*}{ Peer Learning } & Female & 205 & 2.60 & .64 & .045 \\
\hline & Male & 234 & 2.53 & .62 & .041 \\
\hline \multirow{2}{*}{ Using References } & Female & 205 & 3.03 & .64 & .045 \\
\hline & Male & 234 & 3.06 & .63 & .041 \\
\hline
\end{tabular}

The overall trend in the results is firstly examined. The factor Using References received the highest level of agreement in both gender groups. High level positions by means were taken by three factors: Learning Environment, Organizing and Elaborating. In Learning Environment students indicated (see Appendix, Table 5) that they have the most important papers within reach at their desks (both gender equally $82 \%$ marked often or very often) and they design their workplace in a way that makes it easy to find everything $(80.4 \%$ of females and $76.5 \%$ of males marked often or very often). In Organizing factor the highest rates were for organizing subject matter in the way that makes it easy to remember $(89.3 \%$ of female and $73.4 \%$ of male students), structuring the most important points ( $84 \%$ of female and $66.2 \%$ of male students) and underlining the most important parts ( 76.15 of female and $51.3 \%$ of male students) do this often or very often. In Elaborating factor all statements except one (I visualize new issues) were marked by $60-70 \%$ of students as often or very often. Middle positions were taken by three other factors: Attention, Repeating and Peer Learning. From these factor frequencies (see Appendix, Table 5) it can be seen that when students are learning their thoughts tend to stray, $65.1 \%$ of female and $68.8 \%$ of male students marked this happening often or very often, and $60 \%$ of students confirm that they are very easily distracted when they are learning. In Repeating factor, most highly rated statement is I learn key terms by heart in order to remember important facts better in the exam, $74.2 \%$ of female and $63.2 \%$ of male students marked it often or very often. In Peer Learning factor three statements marked by $65-75 \%$ of students often or very often and so one can say that most students turn for help or at least for advice to other students when they do not understand the subject by themselves, or they have considerable gaps in their notes. The lowest levels of agreement occurred in Time Management. So, they are not very keen to use 
time management techniques to help them learn more efficiently considering the time. The only statement $80 \%$ of students confirmed as often used was the decision to choose the times for 601 their learning. This was also the statement excluded from factor analysis because statistically it was too different to fit to the other statements. The results show that students hold positive learning strategies in most factors but there are also some issues they need to change to learn the subject better.

In the Table 3, Levene's test for equality of variances is given and statistics of the $t$-test for equality of means.

\section{Table 3}

Factors independent samples test between gender

\begin{tabular}{|c|c|c|c|c|c|c|c|c|}
\hline \multirow[b]{2}{*}{ Factors } & \multirow[b]{2}{*}{ lariance } & \multicolumn{2}{|c|}{$\begin{array}{l}\text { Levene's Test } \\
\text { for Equality of } \\
\text { Variances }\end{array}$} & \multicolumn{3}{|c|}{$t$-test for Equality of Means } & \multirow[b]{2}{*}{$\begin{array}{l}\text { Mean } \\
\text { Difference }\end{array}$} & \multirow[b]{2}{*}{$\begin{array}{l}\text { Std. Error } \\
\text { Difference }\end{array}$} \\
\hline & & $F$ & $p$ & $t$ & $d f$ & $p$ (2-tailed) & & \\
\hline \multirow{2}{*}{ Organizing } & Equal & 1.011 & .315 & 7.651 & 438 & .001 & .38166 & .04988 \\
\hline & Not equal & & & 7.680 & 435.918 & 1 & .38166 & .04969 \\
\hline \multirow{2}{*}{ Elaborating } & Equal & .257 & .613 & -1.782 & 438 & .075 & -.09102 & .05107 \\
\hline & Not equal & & & -1.778 & 426.849 & .076 & -.09102 & .05118 \\
\hline \multirow{2}{*}{ Repeating } & Equal & .144 & .704 & 3.351 & 438 & .001 & .17134 & .05113 \\
\hline & Not equal & & & 3.345 & 427.229 & .001 & .17134 & .05123 \\
\hline \multirow{2}{*}{ Effort } & Equal & .031 & .861 & 1.406 & 438 & .161 & .06612 & .04703 \\
\hline & Not equal & & & 1.401 & 424.480 & .162 & .06612 & .04719 \\
\hline \multirow{2}{*}{ Attention } & Equal & 2.686 & .102 & .198 & 438 & .843 & .01327 & .06691 \\
\hline & Not equal & & & .199 & 435.589 & .842 & .01327 & .06668 \\
\hline \multirow{2}{*}{ Time Managemen } & Equal & .775 & .379 & .218 & 438 & .827 & .01186 & .05433 \\
\hline & Not equal & & & .217 & 422.584 & .828 & .01186 & .05455 \\
\hline \multirow{2}{*}{$\begin{array}{l}\text { Learning } \\
\text { Environment }\end{array}$} & Equal & .624 & .430 & 1.149 & 438 & .251 & .05952 & .05180 \\
\hline & Not equal & & & 1.149 & 430.427 & .251 & .05952 & .05182 \\
\hline \multirow{2}{*}{ Peer Learning } & Equal & .271 & .603 & 1.178 & 437 & .239 & .07125 & .06047 \\
\hline & Not equal & & & 1.176 & 426.245 & .240 & .07125 & .06058 \\
\hline \multirow{2}{*}{ Using References } & Equal & .062 & .804 & -.562 & 437 & .574 & -.03425 & .06093 \\
\hline & Not equal & & & -.562 & 428.532 & .574 & -.03425 & .06096 \\
\hline
\end{tabular}

From the Table 3 one can see that there are two factors statistically significantly different by gender. Although both male and female respondents tended to agree and disagree with the same components (see Table 5 frequencies), most of the dimensions showed no statistically significant differences by gender. In fact, factors Organising and Repeating are the only 
Indrek KALDO, Kandela ÕUN. Gender differences favouring females in learning strategies in mathematics

PROBLEMS

OF EDUCATION

IN THE $21^{\text {st }}$ CENTURY
Vol. 78, No. 4,2020

Vol. 78, No. 4,2020

602 dimensions which showed statistically significant gender difference at the level $\mathrm{p}=0.01$. In these factors the female respondents were more positive towards learning strategies than males.

In the Table 4, only these statement responses are given, where a statistically significant difference was found. 


\section{Table 4}

Results of the t-test for determining the statistically significant differences of the mean

\begin{tabular}{|c|c|c|c|c|c|}
\hline Factors/Questions & Female & Male & $\begin{array}{l}\text { Mean } \\
\text { Difference }\end{array}$ & $\begin{array}{l}\text { Std. Error } \\
\text { Difference }\end{array}$ & $p$-value \\
\hline \multicolumn{6}{|l|}{ Organizing } \\
\hline $\begin{array}{l}\text { I make charts, diagrams and graphics in order to have } \\
\text { the subject matter in front of me in a structured form }\end{array}$ & 2.39 & 2.10 & .295 & .082 & .0001 \\
\hline $\begin{array}{l}\text { I compile short summaries of the most important contents } \\
\text { as a mnemonic aid. }\end{array}$ & 2.75 & 2.38 & .372 & .087 & .0001 \\
\hline $\begin{array}{l}\text { I go over my notes and structure the most important } \\
\text { points. }\end{array}$ & 3.10 & 2.76 & .341 & .075 & .0001 \\
\hline $\begin{array}{l}\text { I try to order the subject matter in a way that makes it } \\
\text { easy for me to remember. }\end{array}$ & 3.24 & 2.89 & .354 & .069 & .0001 \\
\hline $\begin{array}{l}\text { I compile a summary of the main ideas out of my notes, } \\
\text { the script or other sources }\end{array}$ & 2.76 & 2.45 & .304 & .085 & .0001 \\
\hline $\begin{array}{l}\text { I underline the most important parts in my notes or in the } \\
\text { text }\end{array}$ & 3.16 & 2.45 & .703 & .093 & .0001 \\
\hline $\begin{array}{l}\text { For bigger amounts of subject matter, I find an } \\
\text { arrangement that mirrors the structure best }\end{array}$ & 2.74 & 2.50 & .237 & .077 & .002 \\
\hline $\begin{array}{l}\text { I assemble important terms and definitions in my own } \\
\text { lists }\end{array}$ & 2.89 & 2.44 & .448 & .080 & .0001 \\
\hline \multicolumn{6}{|l|}{ Elaborating } \\
\hline I think of practical applications of new concepts & 2.49 & 2.68 & -.191 & .079 & .015 \\
\hline I visualize new issues & 2.21 & 2.50 & -.290 & .086 & .001 \\
\hline $\begin{array}{l}\text { I wonder if the subject matter is relevant to my everyday } \\
\text { life }\end{array}$ & 2.76 & 2.98 & -.217 & .087 & .013 \\
\hline \multicolumn{6}{|l|}{ Repeating } \\
\hline $\begin{array}{l}\text { I imprint the subject matter from the lecture on my } \\
\text { memory by repeating it }\end{array}$ & 2.49 & 2.32 & .166 & .075 & .028 \\
\hline I read my notes several times in a row & 2.87 & 2.56 & .313 & .084 & .000 \\
\hline $\begin{array}{l}\text { I learn key terms by heart in order to remember important } \\
\text { facts better in the exam }\end{array}$ & 2.90 & 2.68 & .222 & .077 & .004 \\
\hline \multicolumn{6}{|l|}{ Effort } \\
\hline $\begin{array}{l}\text { I make an effort even though the subject matter may not } \\
\text { suit me well }\end{array}$ & 2.97 & 2.80 & .167 & .071 & .018 \\
\hline $\begin{array}{l}\text { I take more time for learning than most of my fellow } \\
\text { students }\end{array}$ & 2.46 & 2.22 & .236 & .086 & .006 \\
\hline \multicolumn{6}{|l|}{ Learning Environment } \\
\hline When studying I make sure that I can work uninterrupted & 2.8 & 2.57 & .232 & .081 & .005 \\
\hline \multicolumn{6}{|l|}{ Peer Learning } \\
\hline $\begin{array}{l}\text { If I find considerable gaps in my notes, I turn to fellow } \\
\text { students }\end{array}$ & 2.86 & 2.69 & .171 & .084 & .044 \\
\hline \multicolumn{6}{|l|}{ Using References } \\
\hline $\begin{array}{l}\text { I look for missing information in different sources, e.g. the } \\
\text { Internet, textbooks, or journals }\end{array}$ & 2.98 & 3.16 & -.178 & .078 & .023 \\
\hline
\end{tabular}


Indrek KALDO, Kandela ÕUN. Gender differences favouring females in learning strategies in mathematics

PROBLEMS

OF EDUCATION

IN THE $21^{\text {st }}$ CENTURY Vol. 78 , No. 4,2020

604

Firstly, some overall trends in the results. In the factor Organizing all of the questions showed statistically significant gender differences. This factor is clearly female marked that means females organize learning strategies better than males. There is also one interesting result - both genders have considerably few respondents $(45,2 \%$ of females and $33.3 \%$ of males) who confirmed that they make charts, diagrams and graphics in order to have the subject matter in a structured form often or very often. In the factor Elaborating, 3 questions out of 8 have gender differences favouring males, but one must notice that the factor Elaborating has no statistically significant difference (see Table 2 and 3) favouring males. The less used learning strategy in Elaboration is the statement I visualize new issues and that matches the same result of Organizing - students are not used to seeing the problems they need to solve as practical problems, they only use formulas not diagrams and they have difficulties to see the united lines between different problems. In the factor Repeating, which is marked positively for females (from Table 2 and 3) 3 questions out of 8 have statistically significant gender differences favouring females. Despite there is no statistically significant difference by gender there are less than $40 \%$ of students who commit a self-compiled compendium to memory or less than $30 \%$ of students read a text and try to recite it at the end of each paragraph. These are two quite important learning strategies to remember the subject. In the factor Effort 2 questions out of 8 have gender differences favouring females and the most frequently (approximately $85 \%$ of students do this often or very often) use learning strategy is that before exams they take the time to go over all the subject matter again and $49.1 \%$ of females and $35,8 \%(p<.01)$ think they study more than their fellow students. In both factors Learning Environment and Peer Learning only one question is statistically significantly favouring females. In factor Peer Learning, it is interesting that approximately $40 \%$ of students use peer students to discuss or ask questions or compare their notes, so the students learn subject mostly alone but asking help if it is needed. In the factor Using References only one question favouring males is statistically significant. Although both male and female respondents tended to agree and disagree with the same components in Attention and Time Management, which showed statistically no significant gender difference in statement comparison.

\section{Discussion}

Most previous studies in Estonia and elsewhere have indicated that male students have more positive views on mathematics. However, there are countries where the female students have a more positive attitude (Li, 2007; Steinthorsdóttir \& Sriraman, 2007). This research confirmed the same aspects of learning strategies as Griese et al. (2015). Current research findings in Estonia coincide with those in Canada, where Li (2007) found female students at the secondary level to have significantly more positive attitudes toward mathematics than male students. Also, current research findings in Estonia coincide with previous works (Kaldo 2014; Kaldo, 2015; Kaldo \& Hannula, 2014) where they found that female students hold more positive view on mathematics than male students. In this study gender differences were found in the two factors Organizing and Repeating. Female students had a more positive view on organizing strategies in mathematics than male students. In this factor, for all the questions, female students answered more positively than male students. Female students structure the most important points, underline the most important parts, they try to make it easy for them to remember. Another important result is the fact that there are gender differences favouring females in such learning strategies as making charts, diagrams and graphics in order to have the subject matter in a structured form that is usually more liked by males but it is interesting that this strategy is used by less than $45 \%$ of respondents. In repeating strategies females read more notes for several times, learn key terms in order to remember important facts, they commit rules, technical terms or formulas to memory and commit a self-compiled compendium to memory. 
So, one can conclude that female students are more persistent than male students to repeat and memorize the subject matter.

For male students compared to female students, the most important is to think about practical applications of new concepts, visualize new issues (but still only $49.6 \%$ of male students do this) and find if the subject matter is relevant to everyday life problems. This is supported by Bergsten's (2007) suggestion for lecturers: in terms of quality, the lecturer must ask why the topic is presented as a lecture, what information is chosen and how it is demonstrated.

In the factor Learning Environment students indicated they have the most important papers within reach at their desks and they design their workplace in a way that makes it easy to find everything and suggestion from the factor Learning Environment is that male as well as female students need extra materials for understanding the subject.

Summarizing, female students value highly technical strategies as organizing work and repeating materials. For male students most important is how to connect the theory with real-life problems. These findings in this research coincide with previous works (Kaldo, 2015; Kaldo \& Hannula, 2014).

Gender differences favouring females in learning strategies in mathematics is a very interesting result. A possible explanation can be that females feel more the need to successfully graduate from university in order to earn a good salary and get a good position in the labour market after graduating university. The findings in this research indicate that females have more positive learning strategies in mathematics in Estonia in their freshman year and other studies indicate that they would even improve after that more than men do. Therefore, the gender difference between older students is likely to be greater than the difference observed among first-year students.

On the other hand, the statement comparison shows some more positive signs for male students. The factor Elaborating is not clearly male marked, but males value more highly the following strategies: they think of practical applications of new concepts, they visualize new issues and wonder if the subject matter is relevant to their everyday life. The factor Using References received the highest level of agreement, which indicates that both, male and female students value highly how to find additional materials and sources. The statement comparison in the factor Using References the male students look more for missing information in different sources, e.g. Internet, textbooks, or journals. In the factor Learning Environment the statement comparison shows that females compared to males make sure while studying that they can work uninterrupted. In the factor Peer Learning female students when they are not sure of something, they ask fellow students for advice.

The factor Using References received the highest level of agreement and is clearly positively marked. The students search for explanatory materials if certain facts are not completely clear for them. Whenever they do not understand a technical term, they look it up in a textbook or on the Internet. When their notes are incomplete, they use additional sources. Based on Alsina (2001) and Bergsten (2007), suggestions are that the students would benefit from additional materials (tutorials, books, lecture notes, web pages, etc.) for studying mathematics at home and practicing using mathematics after lectures.

\section{Conclusions}

This research found several differences between male and female students' learning strategies in mathematics in Estonian universities. The comparison of factors of learning strategies shows that factors Organising and Repeating are clearly gender marked in favour of female students. Females underline the most important parts in their notes or texts, they try to order the subject matter in a way that makes it easy for them to remember, they go over their notes and structure the most important points more than males. Also, females often read their 
Indrek KALDO, Kandela ÕUN. Gender differences favouring females in learning strategies in mathematics

PROBLEMS

OF EDUCATION

IN THE $21^{\text {st }}$ CENTURY Vol. 78 , No. 4, 2020

606

notes several times and learn key terms by heart in order to remember important facts better in exam than males.

It was found that these findings indicate that both males and females find learning strategies in mathematics to be important, as it helps them learn better new subjects. Although the used instrument provided only limited information to identify about possible causes for the gender differences observed among Estonian university students, there have been described some of the ideas about why female students in Estonia might hold more positive learning strategies in mathematics than male students.

The study confirmed the same aspects of learning strategies as previous researches reported. Learning strategies in mathematics are understood as all kinds of planned and conscious learning behaviour and the attitudes behind it, involving observable actions as well as thought processes on the basis of both cognitive and affective-motivational dispositions. This study found that females use organizing learning strategies better than males, and they also use better repeating strategies. Both, males and females found learning strategies to be important and helpful for them. However, some differences in learning strategies beg for caution when importing instruments to new cultural contexts.

A good lecturer must know how to motivate students and must know students' behaviours and learning strategies. A good lecturer explains good teaching strategies to motivate students, increase their interest in mathematics and make them take active participation in a study process. A good lecturer must show students where they can use learning strategies in mathematics in their future jobs. At the tertiary level, there have been too few studies on learning strategies in mathematics- especially for the students of non-mathematical fields of study. This study brings new knowledge about what students at the university level expect of mathematics and from lecturers.

Summarizing, female students held a more positive learning strategies in mathematics than males did. A good lecturer must know how to motivate students to use different learning strategies in mathematics. This study brings new knowledge about what students at the university level expect in mathematics and from lecturers of mathematics.

\section{References}

Abdulwahed, M., Jaworski, B., \& Crawford, A. R. (2012). Innovative approaches to teaching mathematics in higher education: A review and critique. Nordic Studies in Mathematics Education, 17(2), 4968.

Alsina, C. (2001). Why the professor must be a stimulating teacher. In D. A. Holton (Ed.), The teaching and learning of mathematics at the university level: an ICMI Study (pp. 3-12). Kluwer Academic Publishers.

Bergsten, C. (2007). Investigating the quality of undergraduate mathematics lectures. Mathematics Education Research Journal, 19(3), 48-72. https://doi.org/10.1007/BF03217462

De Winter, J. C. F., \& Dodou, D. (2012). Five-point Likert items: $t$ test versus Mann-Whitney-Wilcoxon. Practical Assessment, Research \& Evaluation, 15(11), 1-16. https://doi.org/10.7275/bj1p-ts64

Einaste, I. (2013). Eesti kõrgkoolide matemaatika ja informaatika üliõpilaste enesetõhususe ja motivatsiooni analüüs [Difference between academic motivation and self-efficacy between mathematics and informatics students of Estonian colleges] (Published bachelor's thesis). Tartu University, Estonia.

Else-Quest, N. M., Hyde, J. S. \& Linn, M. C. (2010). Cross-national patterns of gender differences in mathematics: A meta-analysis. Psychological Bulletin, 136(1), 103-127. https://psycnet.apa.org/doi/10.1037/a0018053

Field, A. (2009). Discovering statistics using SPSS (3rd Ed.). Sage Publications.

Forgasz, H. J., Leder, G. C., \& Kloosterman, P. (2004). New perspectives on the gender stereotyping of mathematics. Mathematical Thinking and Learning, 6(4), 389-420. https://doi.org/10.1207/s15327833mt10604_2 
Frost, L. A., Hyde, J. S. \& Fennema, E. (1994). Gender, mathematics performance, and mathematics related attitudes and affect: a meta-analytic synthesis. International Journal of Educational Vol. 78, No. 4, 2020 Research, 21(4), 373-385. https://doi.org/10.1016/S0883-0355(06)80026-1

Griese, B., Lehmann, M., \& Roesken-Winter, B. (2015). Refining questionnaire-based assessment of STEM students' learning strategies. International Journal of STEM Education, 2(1), 12. https://doi.org/10.1186/s40594-015-0025-9

Hyde, J. S., Lindberg, S. M., Linn, M. C., Ellis, A., \& Williams, C. (2008). Gender similarities characterize math performance. Science, 321, 494-495. https://doi.org/10.1126/science.1160364

Hyde, J. S., Fennema, E., \& Lamon, S. J. (1990). Gender differences in mathematics performance: A metaanalysis. Psychological Bulletin, 107, 139-155. https://doi.org/10.1037/0033-2909.107.2.139

Kaldo, I. (2014). What kinds of view of mathematics do students from Estonia hold? Nordic Studies in Mathematics Education, 19(2), 101-122.

Kaldo, I. (2015). University Students' View of Mathematics in Estonia. Doctoral dissertation, Tallinn University, Estonia.

Kaldo, I., \& Hannula, M. S. (2014). Gender differences favouring females in university students' views of mathematics in Estonia. Nordic Studies in Mathematics Education, 19(1), 3-22.

Kaldo, I., \& Õun, K. (2019). Developing of factor structure for learning strategies of Estonian students in mathematics at the university level. Problems of Education in the 21st Century, 77(3), 338. https://doi.org/10.33225/pec/19.77.338

Kislenko, K. (2009). Mathematics is a bit difficult but you need it a lot: Estonian pupils' beliefs about mathematics. In J. Maaß and W. Schlöglmann (Eds.), Beliefs and attitudes in mathematics education: New research results (pp. 143-164). Sense Publishers.

Kislenko, K. (2011). Exploring pupils' beliefs about mathematics: Cases from Estonia and Norway. Doctoral dissertation, University of Agder, Norway.

Li, Q. (2007). Mathematics, science, and technology in secondary schools: Do gender and region make a difference? Canadian Journal of Learning and Technology, 33(1), 41-57.

Lindberg, S. M., Hyde, J. S., Petersen, J. L., \& Linn, M. C. (2010). New trends in gender and mathematics performance: A meta-analysis. Psychological Bulletin, 136(6), 11231135. https://doi.org/10.1037/a0021276

OECD. (2019). PISA 2018: Insights and Interpretations. Author: Andreas Schleicher. https://www.oecd. org/pisa/PISA\%202018\%20Insights\%20and\%20Interpretations\%20FINAL\%20PDF.pdf

Midgley, C., Feldlaufer, H., \& Eccles, J. S. (1989). Student/teacher relations and attitudes toward mathematics before and after the transition to junior high school. Child Development, 60, 981992. https://doi.org/10.2307/1131038

Norman, G. (2010). Likert scales, levels of measurement and the "laws" of statistics. Advances In Health

Sciences Education, 15(5), 625-632. https://doi.org/10.1007/s10459-010-9222-y

Rööp, M. (2013). Matemaatika-informaatikateaduskonna bakalaureuseastme üliõpilase kirjeldus ja oppetöö tulemusi ennustavad tegurid [Learning outcomes predictors of bachelor students in the faculty of mathematics and computer science] (Published bachelor's thesis). Tartu University, Estonia.

Steinthorsdóttir, O. B., \& Sriraman, B. (2007). Girls' belief about the learning of mathematics. The Montana Mathematics Enthusiast. Festschrift in honor of Günter Törner's 60th birthday, 3, 169178.

Wild, K. P., \& Schiefele, U. (1994). Lernstrategien im studium. Ergebnisse zur Faktorenstruktur und Reliabilität eines neuen Fragebogens. Zeitschrift für Differentielle und Diagnostische Psychologie, 15, 185-200. 
Indrek KALDO, Kandela ÕUN. Gender differences favouring females in learning strategies in mathematics

PROBLEMS

OF EDUCATION

IN THE $21^{\text {st }}$ CENTURY

Vol. 78, No. 4,2020

608

\section{Appendix}

Table 5. Statements frequencies comparison by Gender

\begin{tabular}{|c|c|c|c|c|c|}
\hline Statements & Gender & Very rarely & Rarely & Often & $\begin{array}{l}\text { Very } \\
\text { often }\end{array}$ \\
\hline \multicolumn{6}{|c|}{ Organizing } \\
\hline \multirow{2}{*}{$\begin{array}{l}\text { I make charts, diagrams and graphics in order to have the } \\
\text { subject matter in front of me in a structured form. }\end{array}$} & Female & 16 & 38.8 & 35 & 10.2 \\
\hline & Male & 26.9 & 39.7 & 29.9 & 3.4 \\
\hline \multirow{2}{*}{$\begin{array}{l}\text { I compile short summaries of the most important contents as a } \\
\text { mnemonic aid. }\end{array}$} & Female & 8.7 & 26.2 & 46.6 & 18.4 \\
\hline & Male & 21.8 & 29.9 & 37.2 & 11.1 \\
\hline \multirow{2}{*}{ I go over my notes and structure the most important points. } & Female & 2.9 & 13.1 & 54.9 & 29.1 \\
\hline & Male & 7.7 & 26.1 & 48.7 & 17.5 \\
\hline \multirow{2}{*}{$\begin{array}{l}\text { I try to order the subject matter in a way that makes it easy for } \\
\text { me to remember. }\end{array}$} & Female & 1.5 & 9.2 & 52.9 & 36.4 \\
\hline & Male & 5.1 & 20.9 & 53.8 & 20.1 \\
\hline \multirow{2}{*}{$\begin{array}{l}\text { I compile a summary of the main ideas out of my notes, the } \\
\text { script or other sources. }\end{array}$} & Female & 7.8 & 29.1 & 42.7 & 20.4 \\
\hline & Male & 16.2 & 34.6 & 36.8 & 12.4 \\
\hline \multirow{2}{*}{ I underline the most important parts in my notes or in the texts. } & Female & 4.9 & 19 & 31.7 & 44.4 \\
\hline & Male & 23.1 & 25.6 & 34.2 & 17.1 \\
\hline \multirow{2}{*}{$\begin{array}{l}\text { For bigger amounts of subject matter, I find an arrangement } \\
\text { that mirrors the structure best. }\end{array}$} & Female & 4.9 & 32.7 & 45.9 & 16.6 \\
\hline & Male & 11.5 & 36.3 & 42.3 & 9.8 \\
\hline \multirow{2}{*}{ I assemble important terms and definitions in my own lists. } & Female & 3.9 & 25.5 & 48 & 22.5 \\
\hline & Male & 14.5 & 36.8 & 38.5 & 10.3 \\
\hline \multicolumn{6}{|c|}{ Elaborating } \\
\hline \multirow{2}{*}{ I try to find connections to other subjects or courses. } & Female & 9.3 & 28.8 & 43.9 & 18 \\
\hline & Male & 8.1 & 27.8 & 47 & 17.1 \\
\hline \multirow{2}{*}{ I think of practical applications of new concepts. } & Female & 11.2 & 38.5 & 40 & 10.2 \\
\hline & Male & 6.8 & 33.3 & 44.4 & 15.4 \\
\hline \multirow{2}{*}{$\begin{array}{l}\text { I try to relate new terms or theories to terms or theories I } \\
\text { already know. }\end{array}$} & Female & 6.8 & 26.3 & 50.7 & 16.1 \\
\hline & Male & 6.6 & 24.5 & 52.8 & 16.2 \\
\hline \multirow{2}{*}{ I visualize new issues. } & Female & 23.9 & 40 & 27.3 & 8.8 \\
\hline & Male & 13.2 & 37.2 & 35.9 & 13.7 \\
\hline \multirow{2}{*}{$\begin{array}{l}\text { In my mind I try to connect newly learnt facts to what I already } \\
\text { know. }\end{array}$} & Female & 3.4 & 23.8 & 51.5 & 21.4 \\
\hline & Male & 4.7 & 17.9 & 56 & 21.4 \\
\hline \multirow{2}{*}{ I think of practical examples for certain curricular facts. } & Female & 8.3 & 30.7 & 47.3 & 13.7 \\
\hline & Male & 6 & 29.7 & 51.7 & 12.5 \\
\hline \multirow{2}{*}{ I relate what I am learning to my own experiences. } & Female & 3.9 & 20.4 & 52.4 & 23.3 \\
\hline & Male & 6 & 21.4 & 50.9 & 21.8 \\
\hline \multirow{2}{*}{ I wonder if the subject matter is relevant to my everyday life. } & Female & 9.8 & 26.3 & 42 & 22 \\
\hline & Male & 7.3 & 19.8 & 40.5 & 32.3 \\
\hline
\end{tabular}




\begin{tabular}{|c|c|c|c|c|c|}
\hline \multicolumn{6}{|c|}{ Repeating } \\
\hline \multirow{2}{*}{$\begin{array}{l}\text { I imprint the subject matter from the lecture on my memory by } \\
\text { repeating it. }\end{array}$} & Female & 8.8 & 42.4 & 40 & 8.8 \\
\hline & Male & 13.7 & 47.2 & 32.2 & 6.9 \\
\hline \multirow{2}{*}{ I read my notes several times in a row. } & Female & 7.3 & 20.9 & 49.5 & 22.3 \\
\hline & Male & 12.4 & 36.3 & 34.6 & 16.7 \\
\hline \multirow{2}{*}{$\begin{array}{l}\text { I learn key terms by heart in order to remember important facts } \\
\text { better in the exam. }\end{array}$} & Female & 5.9 & 20 & 52.7 & 21.5 \\
\hline & Male & 8.5 & 28.2 & 50.4 & 12.8 \\
\hline \multirow{2}{*}{ I commit a self-compiled compendium to memory. } & Female & 19 & 42.4 & 30.2 & 8.3 \\
\hline & Male & 28.6 & 35.5 & 29.9 & 6 \\
\hline \multirow{2}{*}{ I read the text and try to recite it at the end of each paragraph. } & Female & 37.6 & 34.1 & 22.9 & 5.4 \\
\hline & Male & 40.3 & 33.5 & 21.5 & 4.7 \\
\hline \multirow{2}{*}{ I commit rules, technical terms, or formulas to memory. } & Female & 11.2 & 29.6 & 46.6 & 12.6 \\
\hline & Male & 13.2 & 37.2 & 40.2 & 9.4 \\
\hline \multirow{2}{*}{ I learn the subject matter by heart using scripts or other notes. } & Female & 18 & 28.2 & 43.2 & 10.7 \\
\hline & Male & 16.2 & 43.2 & 33.3 & 7.3 \\
\hline \multicolumn{6}{|l|}{ Effort } \\
\hline \multirow{2}{*}{$\begin{array}{l}\text { Whenever I have planned a certain workload, I make an effort } \\
\text { to master it. }\end{array}$} & Female & 4.9 & 23.3 & 55.3 & 16.5 \\
\hline & Male & 4.7 & 22.3 & 55.4 & 17.6 \\
\hline \multirow{2}{*}{$\begin{array}{l}\text { I make an effort even though the subject matter may not suit } \\
\text { me well. }\end{array}$} & Female & 3.9 & 14.6 & 62.6 & 18.9 \\
\hline & Male & 6.4 & 22.6 & 55.6 & 15.4 \\
\hline \multirow{2}{*}{$\begin{array}{l}\text { I do not give up even though the subject matter is very difficult } \\
\text { and complex. }\end{array}$} & Female & 2.9 & 30.1 & 50.5 & 16.5 \\
\hline & Male & 2.6 & 27.8 & 47.9 & 21.8 \\
\hline \multirow{2}{*}{ I work late at night or at the weekends if necessary. } & Female & 5.9 & 10.2 & 43.4 & 40.5 \\
\hline & Male & 5.2 & 18.5 & 43.3 & 33 \\
\hline \multirow{2}{*}{$\begin{array}{l}\text { It usually does not need much time until I decide to start } \\
\text { working. }\end{array}$} & Female & 15.6 & 34.6 & 38.5 & 11.2 \\
\hline & Male & 13.7 & 32.1 & 41.9 & 12.4 \\
\hline \multirow{2}{*}{$\begin{array}{l}\text { Before exams I take the time to go over all the subject matter } \\
\text { again. }\end{array}$} & Female & 0.5 & 8.7 & 39.3 & 51.5 \\
\hline & Male & 0.4 & 11.2 & 44.6 & 43.8 \\
\hline \multirow{2}{*}{ I take more time for learning than most of my fellow students. } & Female & 15.7 & 35.3 & 36.8 & 12.3 \\
\hline & Male & 22.4 & 41.8 & 27.2 & 8.6 \\
\hline \multirow{2}{*}{ I work until I am sure to pass the exam well. } & Female & 4.9 & 24.3 & 52.9 & 18 \\
\hline & Male & 4.3 & 28.2 & 53.4 & 14.1 \\
\hline \multicolumn{6}{|l|}{ Attention } \\
\hline \multirow{2}{*}{ When I am learning I notice that my thoughts tend to stray. } & Female & 3.9 & 31.1 & 44.7 & 20.4 \\
\hline & Male & 4.3 & 26.9 & 42.3 & 26.5 \\
\hline \multirow{2}{*}{ It is difficult for me to concentrate. } & Female & 8.3 & 41.3 & 37.9 & 12.6 \\
\hline & Male & 11.5 & 42.3 & 32.9 & 13.2 \\
\hline \multirow{2}{*}{ I find myself thinking of completely different things. } & Female & 6.8 & 36.4 & 39.3 & 17.5 \\
\hline & Male & 9.4 & 35 & 38.5 & 17.1 \\
\hline
\end{tabular}


Indrek KALDO, Kandela ÕUN. Gender differences favouring females in learning strategies in mathematics

PROBLEMS

OF EDUCATION

IN THE $21^{\text {st }}$ CENTURY Vol. 78 , No. 4, 2020

610

\begin{tabular}{llllll}
\hline \multirow{2}{*}{ I am easy to distract when learning. } & Male & 16.7 & 43.6 & 28.6 & 11.1 \\
\hline \multirow{2}{*}{ My concentration does not last very long. } & Female & 9.2 & 30.1 & 44.2 & 16.5 \\
\cline { 2 - 6 } Male & 7.3 & 35.5 & 40.2 & 17.1 \\
\cline { 2 - 6 } & Female & 10.2 & 47.1 & 30.6 & 12.1 \\
\hline
\end{tabular}

\begin{tabular}{|c|c|c|c|c|c|}
\hline \multicolumn{6}{|c|}{ Time management } \\
\hline \multirow{2}{*}{ I work according to a schedule. } & Female & 12.2 & 41 & 38 & 8.8 \\
\hline & Male & 15.8 & 40.2 & 36.3 & 7.7 \\
\hline \multirow{2}{*}{ I fix the hours I spend daily on learning in a schedule. } & Female & 33.5 & 41.3 & 18.4 & 6.8 \\
\hline & Male & 38.6 & 35.6 & 19.7 & 6 \\
\hline \multirow{2}{*}{ Before each study period I appoint the duration of my work. } & Female & 34.5 & 40.3 & 19.4 & 5.8 \\
\hline & Male & 40.2 & 34.2 & 21.4 & 4.3 \\
\hline \multicolumn{6}{|c|}{ Learning Environment } \\
\hline \multirow{2}{*}{ I work in a place that makes it easy to concentrate. } & Female & 5.8 & 20.4 & 53.4 & 20.4 \\
\hline & Male & 9.9 & 26.6 & 41.6 & 21.9 \\
\hline \multirow{2}{*}{$\begin{array}{l}\text { I design my work environment in a way that I am distracted as } \\
\text { little as possible. }\end{array}$} & Female & 6.8 & 20.4 & 48.5 & 24.3 \\
\hline & Male & 8.5 & 31.6 & 37.6 & 22.2 \\
\hline \multirow{2}{*}{ When studying I make sure that I can work uninterrupted. } & Female & 5.9 & 27.8 & 46.8 & 19.5 \\
\hline & Male & 10.7 & 37.2 & 36.8 & 15.4 \\
\hline \multirow{2}{*}{$\begin{array}{l}\text { My workplace is designed in a way that makes it easy to find } \\
\text { everything. }\end{array}$} & Female & 3.9 & 15.6 & 57.6 & 22.9 \\
\hline & Male & 3.8 & 19.7 & 53.4 & 23.1 \\
\hline \multirow{2}{*}{ At my desk I have the most important papers within reach. } & Female & 8.3 & 8.8 & 52.7 & 30.2 \\
\hline & Male & 4.7 & 13.2 & 52.1 & 29.9 \\
\hline
\end{tabular}

\begin{tabular}{|c|c|c|c|c|c|}
\hline \multicolumn{6}{|c|}{ Peer Learning } \\
\hline \multirow{2}{*}{ I work on tasks together with my peer students. } & Female & 15.2 & 41.7 & 34.8 & 8.3 \\
\hline & Male & 19.7 & 32.2 & 39.1 & 9 \\
\hline \multirow{2}{*}{$\begin{array}{l}\text { I take my time to discuss the subject matter with other } \\
\text { students. }\end{array}$} & Female & 14.1 & 41.5 & 33.7 & 10.7 \\
\hline & Male & 17.9 & 35.9 & 38.9 & 7.3 \\
\hline \multirow{2}{*}{ I compare my notes with my peer students'. } & Female & 24.6 & 38.4 & 26.1 & 10.8 \\
\hline & Male & 28.2 & 33.8 & 32.1 & 6 \\
\hline \multirow{2}{*}{$\begin{array}{l}\text { I make other students ask me questions on the subject matter } \\
\text { and ask them questions too. }\end{array}$} & Female & 22.1 & 38.2 & 26.5 & 13.2 \\
\hline & Male & 22.9 & 33.3 & 36.4 & 7.4 \\
\hline \multirow{2}{*}{$\begin{array}{l}\text { I turn to help from others when I have serious problems in } \\
\text { understanding something. }\end{array}$} & Female & 3 & 20.7 & 47.3 & 29.1 \\
\hline & Male & 6 & 19.3 & 48.9 & 25.8 \\
\hline \multirow{2}{*}{$\begin{array}{l}\text { When I am not sure about something, I ask a fellow student for } \\
\text { advice. }\end{array}$} & Female & 4.4 & 17.6 & 50.2 & 27.8 \\
\hline & Male & 8.6 & 18 & 47.6 & 25.8 \\
\hline \multirow{2}{*}{ If I find considerable gaps in my notes, I turn to fellow students. } & Female & 7.3 & 23.9 & 44.4 & 24.4 \\
\hline & Male & 12 & 24.4 & 46.6 & 17.1 \\
\hline
\end{tabular}




\begin{tabular}{|c|c|c|c|c|c|}
\hline \multicolumn{6}{|c|}{ Using Reference } \\
\hline \multirow{2}{*}{$\begin{array}{l}\text { I search for explanatory material if certain facts are not } \\
\text { completely clear. }\end{array}$} & Female & 3.9 & 22 & 50.2 & 23.9 \\
\hline & Male & 3.4 & 17.9 & 53.8 & 24.8 \\
\hline \multirow{2}{*}{$\begin{array}{l}\text { Whenever I do not understand a technical term, I look it up in a } \\
\text { textbook or on the Internet. }\end{array}$} & Female & 3.9 & 17.7 & 48.8 & 29.6 \\
\hline & Male & 5.2 & 21.9 & 41.6 & 31.3 \\
\hline \multirow{2}{*}{$\begin{array}{l}\text { I look for missing information in different sources, e.g. the } \\
\text { Internet, textbooks, or journals. }\end{array}$} & Female & 5.4 & 18.1 & 49.5 & 27 \\
\hline & Male & 4.3 & 12.8 & 45.7 & 37.2 \\
\hline \multirow{2}{*}{ When my notes are incomplete, I use additional sources. } & Female & 3.9 & 12.3 & 49.5 & 34.3 \\
\hline & Male & 3.4 & 16.7 & 46.2 & 33.8 \\
\hline
\end{tabular}

\section{Indrek Kaldo}

(Corresponding author)
PhD, Associate Professor, Estonian Business School, A. Lauteri 3, Tallinn 10114, Estonia.

E-mail: indrek.kaldo@ebs.ee

Website: http://www.ebs.ee

Kandela Õun
MSc, Lecturer, University of Tartu Pärnu College, Ringi 35, 80012 Pärnu, Estonia. E-mail: kandela.oun@ut.ee Website: http://www.ut.ee 